\title{
Perbedaan Model Pembelajaran Problem Based Learning dan Project Based Learning Terhadap Peningkatan Kemampuan Berfikir Kritis IPA Siswa SD
}

\section{Anik Suryaningsih ${ }^{1 *}$, Henny Dewi Koeswanti²}

${ }^{12}$ Jurusan Pendidikan Guru Sekolah Dasar, Universitas Kristen Satya Wacana, Salatiga, Indonesia

\section{A R T I C LE I N F O}

\section{Article history:}

Received 1 Januari 2021

Received in revised form 30 Januari 2021

Accepted 1 Maret 2021 Available online 8 April 2021

\section{Kata Kunci:}

model pembelajaran, berfikir kritis, IPA

Keywords: learning model, critical thinking, science

\begin{abstract}
A B S T R A K
Penggunaan model pembelajaran yang kurang kreatif didalam proses pembelajaran menyebabkan rendahnya kemampuan berpikir kritis siswa, sehingga diperlukan model pembelajaran yang kreatif untuk mengembangkan kemampuan berpikir kritis. Penelitian ini bertujuan untuk menganalisis perbedaan pengaruh antara model pembelajaran Problem Based Learning dan Project Based Learning terhadap peningkatan kemampuan berfikir kritis IPA siswa SD. Penelitian ini merupakan termasuk kedalam jenis penelitian meta analisis. Subjek didalam penelitian ini adalah 20 artikel penggunaan model pembelajaran Problem Based Learning dan Project Based Learning. Pengumpulan data penelitian dilakukan dengan cara mencari artikel-artikel yang terdapat pada jurnal online dengan menggunakan Google Cendikia dan Scholar. Instrumen yang digunakan berupa lembaran pemberian kode (coding category). Teknik analisis data yang digunakan adalah analisis statistik kuantitatif. Hasil penelitian yang telah dilakukan yaitu perbandingan model pembelajaran Problem Based Learning mengalami peningkatan rata-rata sebesar 24,48 lebih besar dari model pembelajaran Project Based Learning
\end{abstract} sebesar 17,31, hasil uji Ancova membuktikan f hitung f tabel yakni 11,620 > 3,55 dan signifikasinya 0,002 < 0,05, dan Uji Effect Size sebesar 0,234 dengan nilai Sig. 0,002. Simpulan penelitian ini adalah model pembelajaran Problem Based Learning lebih efektif untuk mempengaruhi peningkatan kemampuan berfikir kritis IPA siswa SD dibandingkan dengan model pembelajaran Project Based Learning. Implikasi penelitian ini adalah dapat mengembangkan keterampilan pemecahan masalah, dan memperoleh konsep yang esensial berdasarkan materi pelajaran IPA.

\begin{abstract}
A B S T R A C T
The use of less creative learning models in the learning process causes students to have low critical thinking skills, so a creative learning model is needed to develop critical thinking skills. This study aims to analyze the difference in the effect of the Problem Based Learning and Project Based Learning models on improving the critical thinking skills of elementary students. This research is included in the type of meta-analysis research. The subjects in this study were 20 articles using the Problem Based Learning and Project Based Learning models. Research data collection was carried out by searching for articles in online journals using Google Scholar and Scholar. The instrument used was a coding category sheet. The data analysis technique used is quantitative statistical analysis. The results of the research that have been carried out are the comparison of the Problem Based Learning learning model which has an average increase of 24.48 which is greater than the Project Based Learning learning model of 17.31, the Ancova test results prove $f$ count $f$ table namely $11.620>3.55$ and its significance $0.002<0.05$, and the Effect Size Test of 0.234 with a Sig. 0.002. The conclusion of this study is that the Problem Based Learning learning model is more effective in influencing the improvement of elementary students' critical thinking skills in science compared to the Project Based Learning learning model. The implication of this research is that it can develop problem-solving skills and obtain essential concepts based on science subject matter.
\end{abstract}




\section{Pendahuluan}

Pembelajaran pada hakikatnya adalah sebuah proses dimana terdapat komponen mengatur, mengorganisasikan lingkungan yang terdapat disekitar siswa sehingga dapat mendorong dan mewujudkan proses belajar yang baik (Ponorogo, 2016; K. L. Purwanti, 2017; Shafa, 2014). Tujuan belajar yang paling penting adalah untuk membantu kegiatan belajar dengan cara yang lebih mudah didalam penguasaan prinsip dasar dalam mengembang sikap positif yang terdapat dalam belajar serta mencari solusi pemecahan masalah yang sesuai dengan kemampuan sendiri (Kurniaman \& Noviana, 2017; Subadi et al., 2013; Sugiyanto et al., 2015). Mata pelajaran Ilmu pengetahuan alam yang mempelajari tentang gejala alam berupa fakta, konsep dan hukum yang telah teruji kebenarannya melalui rangkaian penelitian. Pembelajaran IPA yang diharapkan dapat membantu siswa untuk memahami fenomena-fenomena alam (Ardithayasa \& Yudiana, 2020; Hartana et al., 2016; Marudut et al., 2020). Menginagat pentinganya pembelajaran IPA, maka pembelajaran yang dilaksanakan sebaiknya dapat memberikan siswa bekal kemampuan berfikir kritis, diharapkan kemampuan berfikir kritis siswa ini akan menjadi lebih terarah dan maksimal karena kemampuan berfikir kritis sangat penting diterapkan dalam kurikulum 2013, dimana dalam pelaksanaan kurikulum 2013 siswa dituntut untuk dapat berperan aktif dalam kegiatan proses pembelajaran dan peran guru hanya sebagai fasilitator saja (Christiana et al., 2014; Kristiyanto, 2020; Putri, 2019).

Peran guru di dalam kegiatan proses pembelajaran tetaplah menjadi salah satu kunci sukses sebuah pendidikan (Dardiri et al., 2017; Nursalim, 2017; K. Purwanti et al., 2014). Guru berperan dalam merancang, melaksanakan dan mengevaluasi pembelajaran. Dalam proses merencanakan pembelajaran, guru perlu memilih model pembelajaran yang dapat meningkatkan kemampuan berfikir kritis siswa dalam pembelajaran IPA. Pembelajaran yang inovatif dan efektif dalam pembelajaran IPA diperlukan supaya siswa dapat berperan aktif dalam proses pembelajaran dan guru pun harus memilih model pembelajaran yang sesuai dengan materi IPA secara keseluruhan merupakan belajar memecahkan masalah (Istiandaru et al., 2015; Ramlawati et al., 2017; Wajdi, 2017).

Namun kenyatannya, kualitas proses dan produk pendidikan yang kita alami masih kurang memadai. Terlebih lagi proses maupun produk harus bedampingan sejajar dengan alasan atau pertimbangan yakni apabila prosesnya sesuai maka bagian akhir yang diharapkan adalah produknya juga baik dan sesuai arti proses pembelajaran yang terselenggara dengan segala bentuk usaha yang maksimal akan membawa dampak pada produk yang baik yaitu hasil yang diperoleh dari belajar siswa. Hal ini dibuktikan dengan pelaksanaan kurikulum 2013, siswa masih belum banyak mendapatkan kesempatan untuk dapat banyak berpartisipasi secara aktif dan mengembangkan kemampuan berfikir kritisnya dalam kegiatan proses pembelajaran yang didilakukan disekolah (Ardianingsih et al., 2017; Indriani, 2015; Kurniasari, 2017). Oleh sebab itu perlu adanya inovasi atau desain pembelajaran yang menarik salah satunya pada pembelajaran IPA di SD.

Salah satu model pembelajaran yang banyak diadopsi untuk menunjang pendekatan pembelajaran yang dapat melibatkan siswa yang berpusat pada keaktifan siswa yaitu model Pembelajaran Prolem Based Learning dan model Pembelajaran Project Based Learning. Problem Based Learning adalah suatu pendekatan pembelajaran yang memakai masalah konkret menjadi suatu konteks bagi siswa buat belajar mengenai cara berpikir kritis \& keterampilan pemecahan masalah, serta buat memperoleh pengetahuan \& konsep yg esensial berdasarkan materi pelajaran (Febriana et al., 2020; Fitri et al., 2020; Sribawana et al., 2017). Sedangkan model pembelajaran Project Based Learning merupakan sebuah model pembelajaran yang berorientasi pada siswa dan guru sebagai fasilitator ataupun motivator dimana siswa dapat menghasilkan sebuah proyek atau karya (Mustika \& Ain, 2020; Wajdi, 2017; Wijanarko et al., 2017). Penelitian ini didukung dengan beberapa penelitian sebelumnya yang relevan seperti: (1) penelitian yang dilakukan oleh (Gunantara et al., 2014), yang memperoleh hasil penelitian bahwa penerapan model pembelajaran problem based learning berpengaruh terhadap peningkatan kemampuan pemecahahan masalah; (2) penelitian yang dilakukan oleh (Ariswati, 2018), yang memperoleh hasil penelitian bahwa model pembelajaran problem based learning berpengaruh terhadap hasil belajar siswa pada mata pelajaran matematika; (3) penelitian yang dilakukan oleh (Wijanarko et al., 2017), yang memperoleh hasil penelitian bahwa model project based learning terbimbing terbukti efektif untuk meningkatkan keterampilan proses sains dan hasil belajar IPA.Tujuan dilaksanakannya penelitian ini adalah untuk menganalisis perbedaan pengaruh 
antara model pembelajaran Problem Based Learning dan Project Based Learning terhadap peningkatan kemampuan berfikir kritis IPA siswa SD.

\section{Metode}

Penelitian merupakan termasuk kedalam jenis penelitian meta analisis data. Meta analisis merupakan penelitian yang dilakukan dengan cara merangkum data, mereview, dan menganalisis hasil data. Pada metode meta-analisis dengan mengkaji beberapa artikel pada jurnal nasional. Didalam penelitian ini memanfaatkan bahan ajar buku atau jurnal sebagai sumber informasi yang diperlukan. Penelitian yang akan dilakukan yaitu menggunakan model pembelajaran Problem Based Learning dan Project Based Learning.

Subjek didalam penelitian ini adalah tentang artikel publikasi ilmiah berupa artikel-artikel jurnal online seperti jurnal nasional penggunaan model pembelajaran Problem Based Learning dan Project Based Learning antara tahun 2011-2020. Kata kunci yang dapat digunakan untuk dapat menemukan artikel adalah "Problem Based Learning", "Project Based Learning", "Kemampuan Berfikir Kritis IPA", dari menggunakan kata kunci untuk mencari beberapa artikel yang menguji kriteria penelitian.

Pengumpulan data penelitian dilakukan dengan cara mencari artikel-artikel yang terdapat pada jurnal online dengan menggunakan Google Cendikia dan Scholar. Beberapa artikel yang dapat digunakan sebagai data dalam penelitian harus memenuhi syarat dalam kriteria penilaian terdapat data sebelum perlakuan dan sesudah diberikan perlakuan dalam bentuk skor persentase rata-rata, dengan sampel sebanyak 20 artikel dan instrumen berupa lembaran pemberian kode (coding category). Adapun beberapa tahapan yang digunakan untuk pemberian kode data guna untuk mendapatkan informasi yaitu, penomoran kode, sub judul penelitian, penulis atau nama peneliti, tahun penelitian, dan model pembelajaran yang digunakan.

Teknik analisis data yang digunakan adalah analisis statistik kuantitatif untuk bertujuan menganalisis hasil tes yang telah dilakukan untuk mengetahui keefektifan antara dua model pembelajaran. Analisis data yang digunakan didalam uji prasyarat antara lain uji normalitas, homogenitas, linearitas dan effect size. Hasil Uji prasyarat ini yang akan dilakukan sebelum melakukan uji Ancova. Uji Ancova untuk mengetahui pengaruh dari perbedaan model pembelajaran antara Problem Based Learning dan Project Based Learning terhadap kemampuan berfikir kritis

\section{Hasil dan Pembahasan}

Penelitian meta analisis ini bertujuan untuk mengetahui dan menguji apakah terdapat perbedaan efektivitas yang signifikan antara model pembelajaran Problem Based Learning dan Project Based Learning ditinjau dari peningkatan kemampuan berfikir kritis IPA siswa sekolah dasar. Dari hasil penelitian yang telah diperoleh yaitu 20 artikel terkait dengan model pembelajaran Problem Based Learning dan Project Based Learning dalam meningkatkan kemampuan berfikir kritis siwa sekolah dasar. Pengolahan data artikel dengan cara merangkum, mengumpulkan data dan mencari artikel-artikel yang terdapat pada jurnal online dengan menggunakan Google Cendikia dan Scholar yang akan digunakan sebagai sampel artikel terkait dengan model pembelajaran Problem Based Learning dan Project Based Learning. Dengan menentukan effect size dari setiap penelitian, maka peneliti dapat menemukan dan menentukan besar pengaruh suatu perlakuan. variable bebas yaitu variable yang menjelaskan dan mempengaruhi variable lain dan variable terikat merupakan variable yang dijelaskan dan dipengaruhi oleh variable bebas. Variabel Bebas (variabel X) yang digunakan adalah model pembelajaran Problem Based Learning dan Project Based Learning.Variabel Terikat (variable Y) yang digunakan ialah kemampuan berfikir kritis IPA. Apabila mendapatkan artikel ilmilah yang sesuai maka dihitung menggunakan SPSS dengan tujuan menyajikan kembali hasil perhitungan 20 artikel sejenis tersebut, informasi yang telah diperoleh kemudian disajikan kembali secara mendeskripsikannya secara kuantitatif. Data hasil analisis model Problem Based Learning dapat dilihat pada Tabel 1. 
Tabel 1. Persentase Menggunakan Model Pembelajaran Problem Based Learning

\begin{tabular}{cccc}
\hline \multirow{2}{*}{ Kode Data } & \multicolumn{3}{c}{ Persentase (\%) } \\
\cline { 2 - 4 } & Skor Pretest & Skor Posttest & Peningkatan \\
\hline 1P & 56,45 & 85,30 & 28,85 \\
2P & 50,1 & 79,16 & 29,06 \\
3P & 53,63 & 74,19 & 20,25 \\
$4 \mathrm{P}$ & 67,61 & 69,03 & 1,42 \\
5P & 24,00 & 83,75 & 59,75 \\
6P & 51,93 & 82,09 & 30,16 \\
7P & 53,65 & 79,48 & 25,83 \\
8P & 62,92 & 72,08 & 9,16 \\
9P & 69,00 & 79,35 & 10,35 \\
10P & 39 & 69 & 30 \\
\hline Rata-rata & $\mathbf{5 2 , 8 3}$ & $\mathbf{7 7 , 3 4}$ & $\mathbf{2 4 , 4 8}$ \\
\hline
\end{tabular}

Persentase rata-rata peningkatan kemampuan berfikir kritis IPA menggunakan model pembelajaran pembelajaran Problem Based Learning terdapat skor terendah sebesar 1,42\% dan skor tertinggi sebesar 59,75\% dengan rata-rata sebesar 24,48\%. Berikut data hasil analisis model pembelajaran Project Based Learning, dapat dilihat pada Tabel 2.

Tabel 2. Persentase Menggunakan Model Pembelajaran Project Based Learning

\begin{tabular}{cccc}
\hline \multirow{2}{*}{ Kode Data } & \multicolumn{3}{c}{ Persentase (\%) } \\
\cline { 2 - 4 } & Skor Pretest & Skor Posttest & Peningkatan \\
\hline 1P & 50,86 & 81,57 & 30,71 \\
2P & 75 & 83 & 8 \\
3P & 29,14 & 58 & 28,86 \\
$4 \mathrm{P}$ & 44,13 & 44,39 & 0,26 \\
$5 \mathrm{P}$ & 34,67 & 69,52 & 34,85 \\
6P & 52,75 & 66,13 & 13,38 \\
7P & 64,31 & 81,34 & 17,03 \\
8P & 72,90 & 79,90 & 7 \\
9P & 6 & 24 & 18 \\
10P & 64,80 & 79,84 & 15,04 \\
\hline Rata-rata & $\mathbf{4 9 , 4 7}$ & $\mathbf{6 6 , 7 7}$ & $\mathbf{1 7 , 3 1}$ \\
\hline
\end{tabular}

Persentase rata-rata peningkatan kemampuan berfikir kritis IPA menggunakan model pembelajaran pembelajaran Project Based Learning terdapat skor terendah sebesar 0,26\% dan perolehehan nilai skor tertinggi sebesar 34,85\% dengan nilai rata-rata sebesar $17,31 \%$. Persentase Menggunakan Model Pembelajaran Project Based Learning dpat dilihat pada Tabel 3.

Tabel 3. Persentase Menggunakan Model Pembelajaran Project Based Learning

\begin{tabular}{cccc}
\hline Pengukuran & \multicolumn{2}{c}{ Rata-Rata Skor (Mean) } & \multirow{2}{*}{ Selisih } \\
& \multirow{2}{*}{ Problem Based Learning } & $\begin{array}{c}\text { Project Based } \\
\text { Learning }\end{array}$ & \\
\hline Pretest & $52,83 \%$ & $77,34 \%$ & $24,51 \%$ \\
Posttest & $49,47 \%$ & $66,77 \%$ & $17,3 \%$ \\
\hline
\end{tabular}

Berdasarkan hasil pengukuran komparasi data dari rata-rata antara skor pretest model pembelajaran Problem Based Learning dan Project Based Learning mempunyai selisih sebesar 24,51\% sedangkan rata-rata skor posttest model pembelajaran Problem Based Learning dan Project Based Learning mempunyai selisih sebesar 17,3\%. Berikut ini merupakan diagram komparasi antara model pembelajaran Problem Based Learning dan Project Based Learning dapat dilihat pada Gambar 1. 


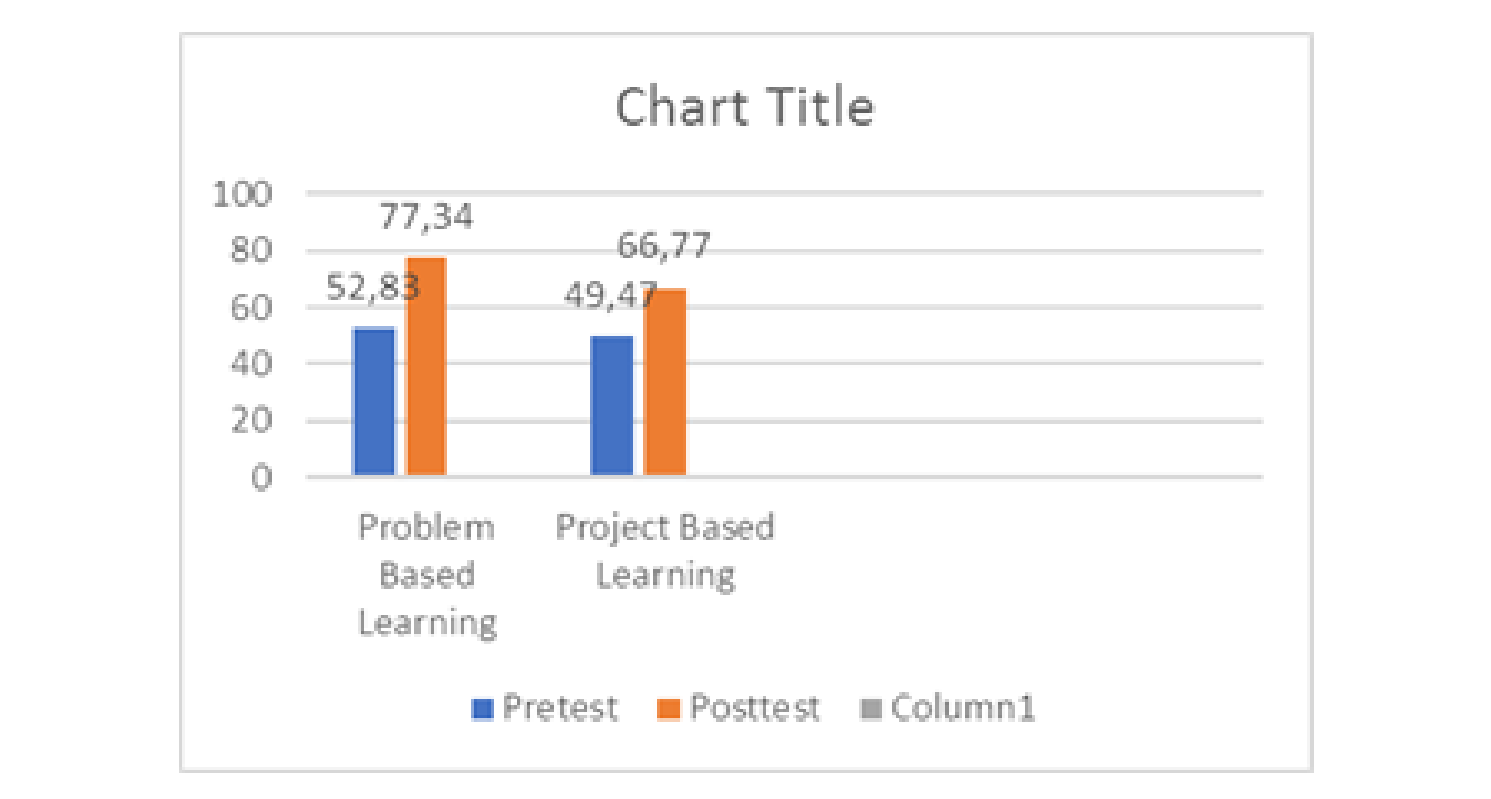

\section{Gambar 1. Diagram Komparasi Antara Model Pembelajaran Problem Based Learning Dan Project Based Learning}

Berdasarkan Gambar 1, maka dapat disimpulkan bahwa terdapat hasil peningkatan skor pretest ke posttest dari setiap model pembelajaran Problem Based Learning dan Project Based Learning. Diantaranya adalah peningkatan nilai pretest PBL yakni 52,83\% setelah diberikan posttest skornya menjadi 77,34\% sedangkan nilai pretest Pjbl 49,47\% setelah diberikan posttest menjadi 66,77\%. Masing-masing model pembelajaran mengalami peningkatan skor pretest dan posttest.

Sebelum dilakukan uji mancova dilakukan uji prasyarat yang memperoleh hasil yaitu: (1) hasil uji normalitas data pada tingkat signifikasi skor pretest model pembelajaran Problem Based Learning yaitu 0,300 > 0,05 dapat berarti berdistribusi normal, tingkat signifikasi skor posttest model pembelajaran Problem Based Learning yaitu 0,330 > 0,05 dapat berarti berdistribusi normal, tingkat signifikasi skor pretest model pembelajaran Project Based Learning yaitu 0,559>0,05 dapat berarti berdistribusi normal, tingkat signifikasi skor posttest model pembelajaran Project Based Learning yaitu 0,025 > 0,05 dapat berarti berdistribusi normal; (2) hasil uji homogenitas berdasarkan pada nilai hasil uji homogenitas signifikasinya adalah 0,143 >0,05. Berdasarkan perolehan hasil data tersebut dapat disimpulan bahwa model pembelajaran Problem Based Learning dan Project Based Learning mempunyai variansi homogen atau sama; (3) hasil uji homogenitas berdasarkan pada nilai hasil uji homogenitas signifikasinya adalah $0,018>0,05$, berdasarkaan perolehan hasil data tersebut dapat disimpulkan bahwa model pembelajaran Problem Based Learning dan Project Based Learning mempunyai variansi homogen atau sama; (4) hasil uji linearitas yang terdapat pada skor nilai pretest dan posttest model pembelajaran Problem Based Learning dan Project Based Leaning dilihat dari salah satu statistik, yaitu statistik yang dilakukan dengan Deviation from Linearity, menunjukkan hasil uji linearitas pretest dan posttest memperoleh signifikasi 0,850 $>0,05$ yang dapat diartikan bahwa skor nilai pretest dan posttest model pembelajaran Problem Based Learning mempunyai hubungan yang dapat dikatakan linear; (5) hasil uji linearitas berdasarkan tabel diatas dapat disimpulkan bahwa uji linearitas skor pretes dan posttest model pembelajaran Problem Based Learning dan Project Based Leaning sesuai dengan statistik, yaitu statistik yang dilakukan dengan Deviation from Linearity, hasil uji linearitas nilai skor pretest dan posttest yang diperoleh yaitu signifikasi 0,559 $>0,005$ yang berarti bahwa nilai skor pretest dan posttest model pembelajaran Problem Based Learning mempunyai hubungan yang dapat dikatakan linear.

Selanjutnya, uji Ancova pada model pembelajaran0Problem Based Learning memiliki jumlah artikel sebanyak 10 dengan rata-rata 78,9660. Sedangkan pada model pembelajaran Project Based Learning dengan jumlah artikel sebanyak 10 mempunyai rata-rata 59,2414 . Sehingga dari hasil tersebut terdapat perbedaan antara model pembelajaran Problem Based Learning dan Project Based Learning ditinjau dari peningkatan kemampuan berfikir kritis IPA. Model pembelajaran Problem Based Learning hasilnya lebih tinggi dibandingkan model pembelajaran Project Based Learning. 
Hasil uji ancova yang dilakukan pada model pembelajaran mempunyai nilai signifikasi0yakni sebesar 0,002 . F hitung yang dapat diperoleh adalah 11,620. Sesuai dengan hasil perhitungan hipotesis dengan menggunakan uji Ancova Univariate yang menunjukkan nilai signifikasi sebesar 0,002 yang berartikan lebih kecil dari 0,05 $(0,002<0,05)$. Dari hasil uji Ancova membuktikan $\mathrm{f}$ hitung $\mathrm{f}$ tabel yakni $11,620>3,55$ dan signifikasinya 0,002 < 0,05 yang membuktikan bahwa Ho ditolak dan Ha diterima.0Hal ini menunjukan bahwa terdapat perbedaan yang signifikan antara penggunaan model pembelajaran Problem Based Learning dan Project Based Learning ditinjau dari peningkatan kemampuan berfikir kritis IPA siswa SD. Dapat dilihat bahwa penggunaan model pembelajaran Problem Based Learning mempunyai nilai rata-rata skor 78,96 dan model Project Based Learning mempunyai nilai rata-rata skor 59,24. Pada kemampuan berfikir kritis siswa yang lebih unggul 78,96 adalah model pembelajaran Problem Based Learning ketimbang Project Based Learning 59,24. Maka ini ditunjukan melalui uji ancova bahwa model pembelajaran Problem Based Learning lebih efektif dalam mempengaruhi peningkatan kemampuan berfikir kritis dibandingkan dengan model pembelajaran Project Based Learning. Setelah ini akan dilanjutkan dengan uji effect size untuk mengetahui pengaruh terhadap kemampuan berpikir kritis siswa.

Uji effect size dengan menggunakan uji Ancova0menggunakan model pembelajaran Problem Based Learning dan Project Based Learning terdapat hasil sebesar 0,234 dengan nilai Sig. 0,002.0Maka dari hasil uji ini menunjukan bahwa dalam model pembelajaran Problem Based Learning dan Project Based Learning dapat memberikan pengaruh terhadap peningkatan kemampuan berfikir kritis IPA siswa SD. Hal ini terjadi karna pembelajaran yang digunakan efektif digunakan pada pembelajaran IPA untuk mengembangkan kemampuan berpikir kritis siswa.

Pembelajaran yang inovatif dan efektif dalam pembelajaran IPA diperlukan supaya siswa dapat berperan aktif dalam proses pembelajaran dan guru pun harus memilih model pembelajaran yang sesuai dengan materi IPA secara keseluruhan merupakan belajar memecahkan masalah (Istiandaru et al., 2015; Ramlawati et al., 2017; Wajdi, 2017). Model pembelajaran yang diberikan kepada peserta didik juga harus sesuai dengan karakteristiknya, memunculkan sebuah pengalaman dan wawasan baru untuk peserta didik dan juga gurunya Problem Based Learning adalah suatu pendekatan pembelajaran yang memakai masalah konkret menjadi suatu konteks bagi siswa buat belajar mengenai cara berpikir kritis \& keterampilan pemecahan masalah, serta buat memperoleh pengetahuan \& konsep yg esensial berdasarkan materi pelajaran (Febriana et al., 2020; Fitri et al., 2020; Sribawana et al., 2017). Sedangkan model pembelajaran Project Based Learning merupakan sebuah model pembelajaran yang berorientasi pada siswa dan guru sebagai fasilitator ataupun motivator dimana siswa dapat menghasilkan sebuah proyek atau karya (Mustika \& Ain, 2020; Wajdi, 2017; Wijanarko et al., 2017). Perlunya guru memilih model pembelajaran yang dapat meningkatkan kemampuan berfikir kritis siswa dalam pembelajaran IPA supaya dapat terlaksana dengan baik. Kemampuan berfikir kritis siswa dapat meningkat apabila guru memberikan dorongan atau membiasakan dengan kegiatan pembelajaran yang melibatkan kemampuan berfikir kritis. (Hazmiwati, 2018; Mustika, 2017; Rusman, 2014) mengutarakan pendapatnya bahwa rendahnya prestasi sains di Indonesia dapat dipengaruhi berfikir kritis siswa terhadap sebuah persoalan atau permasalahan yang dihadapi oleh kemampuan oleh siswa. Hal ini mewajibkan guru untuk mampu mengembangkan kemampuan berfikir kritis yang ada pada diri siswa.

Penelitian ini didukung dengan beberapa penelitian sebelumnya yang relevan seperti: (1) penelitian yang dilakukan oleh (Gunantara et al., 2014), yang memperoleh hasil penelitian bahwa penerapan model pembelajaran problem based learning berpengaruh terhadap peningkatan kemampuan pemecahahan masalah; (2) penelitian yang dilakukan oleh (Ariswati, 2018), yang memperoleh hasil penelitian bahwa model pembelajaran problem based learning berpengaruh terhadap hasil belajar siswa pada mata pelajaran matematika; (3) penelitian yang dilakukan oleh (Wijanarko et al., 2017), yang memperoleh hasil penelitian bahwa model project based learning terbimbing terbukti efektif untuk meningkatkan keterampilan proses sains dan hasil belajar IPA. Implikasi penelitian meta analisis ini tentang perbedaan pengaruh antara model pembelajaran Problem Based Learning dan Project Based Learning terhadap peningkatan kemampuan berfikir kritis IPA siswa SD adalah dapat mengembangkan keterampilan pemecahan masalah, dan memperoleh konsep yang esensial berdasarkan materi pelajaran IPA. 


\section{Simpulan}

Berdasarkan hasil analisis yang telah dilakukan bahwa model pembelajaran Problem Based Learning lebih efektif dalam mempengaruhi peningkatan kemampuan berfikir kritis IPA siswa SD dibandingkan dengan model pembelajaran Project Based Learning, jadi kedua model pembelajaran ini saat sudah dilakukan uji analisis data mempunyai perbedaan yang signifikan. Implikasi penelitian ini adalah dapat mengembangkan keterampilan pemecahan masalah, dan memperoleh konsep yang esensial berdasarkan materi pelajaran IPA.

\section{Daftar Pustaka}

Ardianingsih, F., Mahmudah, S., \& Rianto, E. (2017). Peran Guru Dalam Implementasi Kurikulum 2013 Pendidikan Khusus Pada Sekolah Luar Biasa Di Sidoarjo. Jurnal Pendidikan, 2(1), 14-20. https://doi.org/10.26740/jp.v2n1.p21-30

Ardithayasa, I. W., \& Yudiana, K. (2020). Model Pembelajaran Group Investigation (GI) Berbasis Tri Hita Karana Terhadap Hasil Belajar IPA. Jurnal Ilmiah Sekolah Dasar, 4(2), 163-173. https://doi.org/10.238872Fjisd.v4i2.25105

Ariswati, N. P. E. A. (2018). Pengaruh Model Pembelajaran Problem Based Learning Terhadap Hasil Belajar Matematika Siswa Kelas V Sd Negeri Nanggulan. Mimbar PGSD, 6(4). https://doi.org/10.1590/s1809-98232013000400007

Christiana, P. P., Suniasih, N. W., \& Suadnyana, I. N. (2014). Pengaruh Model Problem Based Learning Berbasis Penilaian Proyek terhadap Kemampuan Berpikir Kritis IPA SD Gugus VIII Sukawati. EJournal Mimbar PGSD Universitas Pendidikan Ganesha, 2(1). https://doi.org/10.23887/jjpgsd.v2i1.2031

Dardiri, A., Mujiyono, M., \& Ichwanto, M. A. (2017). Analisis Hasil Uji Kompetensi Guru Sekolah Menengah Kejuran Bidang Keahlian Teknik Bangunan. Teknologi Dan Kejuruan: Jurnal Teknologi, Kejuruan, Dan Pengajarannya, 40(2), 193-203. https://doi.org/10.17977/um031v40i22017p193

Febriana, R., Yusri, R., \& Delyana, H. (2020). Modul Geometri Ruang Berbasis Problem Based Learning Terhadap Kreativitas Pemecahan Masalah. Aksioma: Jurnal Program Studi Pendidikan Matematika, 9(1), 93. https://doi.org/10.24127/ajpm.v9i1.2591

Fitri, M., Yuanita, P., \& Maimunah, M. (2020). Pengembangan Perangkat Pembelajaran Matematika Terintegrasi Keterampilan Abad 21 Melalui Penerapan Model Problem Based Learning (PBL). Jurnal Gantang, 5(1), 77-85. https://doi.org/10.31629/jg.v5i1.1609

Gunantara, G., Suarjana, M., \& Riastini, P. N. (2014). Penerapan Model Pembelajaran Problem Based Learning Untuk Meningkatkan Kemampuan Pemecahahan Masalah Matematika Siswa Kelas IV. Jurnal Mimbar PGSD Universitas Pendidikan Ganesha, 2(1). https://doi.org/10.15294/kreano.v10i2.19671

Hartana, A., Setyosari, P., \& Kuswandi, D. (2016). Penerapan Strategi Pembelajaran Paradigma Pedagogi Ignatian (Reflektif) Terhadap Peningkatan Hasil Belajar Dan Motivasi Berprestasi Belajar Ilmu Pengetahuan Alam (IPA) Siswa Kelas V. Teori, Penelitian, Dan Pengembangan, 1(4), 765-779. https://doi.org/10.17977/jp.v1i4.6555

Hazmiwati, H. (2018). Penerapan Model Pembelajaran Kooperatif Tipe Stad Untuk Meningkatkan Hasil Belajar IPA Siswa Kelas II Sekolah Dasar. Primary: Jurnal Pendidikan Guru Sekolah Dasar, 7(1), 178. https://doi.org/https://doi.org/10.33578/jpfkip.v7i1.5359

Indriani, A. (2015). Penerapan Pembelajaran Tematik Kurikulum 2013 oleh Guru SD/MI di Desa Klepek Kecamatan Sukosewu Kabupaten Bojonegoro Semester Gasal Tahun Ajaran 2014/2015. Jurnal Varidika, 27(1), 43-49. https://doi.org/10.23917/varidika.v27i1.738

Istiandaru, A., Istihapsari, V., Wardono, \& Mulyono. (2015). Problem Based Learning (PBL) dengan Pendekatan Realistik-Saintifik dan Asesmen PISA untuk Meningkatkan Kemampuan Literasi 
Matematika. Edumatica, 5(1), 1-11. https://doi.org/10.22437/edumatica.v5i01.2670

Kristiyanto, D. (2020). Peningkatan Kemampuan Berpikir Kritis dan Hasil Belajar Matematika dengan Model Project Based Learning (PJBL). Mimbar Ilmu, 25(1), 1-10. https://doi.org/10.23887/mi.v25i1.24468

Kurniaman, O., \& Noviana, E. (2017). Penerapan Kurikulum 2013 Dalam Meningkatkan Keterampilan, Sikap, Dan Pengetahuan. Primary: Jurnal Pendidikan Guru Sekolah Dasar, 6(2). https://doi.org/10.33578/jpfkip.v6i2.4520

Kurniasari, F. (2017). Implementasi Pendekatan Saintifik Pada Penugasan Aktivitas Di Buku Teks Bahasa Indonesia Kelas VII SMP Berdasarkan Kurikulum 2013. Jurnal Pendidikan Edutama, 4(1), 9-26. https://doi.org/10.30734/jpe.v4i1.44

Marudut, M. R. H., Bachtiar, I. G., Kadir, \& Iasha, V. (2020). Peningkatan Kemampuan Berpikir Kritis Dalam Pembelajaran IPA Melalui Pendekatan Keterampilan Proses. Jurnal Basicedu, 4(3), 577585. https://doi.org/10.31004/basicedu.v4i3.401

Mustika, D. (2017). Pembelajaran Menggunakan Model Learning Cycle 5E untuk Meningkatkan Hasil Belajar IPA di Sekolah Dasar. Jurnal Handayani, 7(2), 1-10. https://doi.org/10.24114/jh.v7i2.7230

Mustika, D., \& Ain, S. Q. (2020). Peningkatan Kreativitas Mahasiswa Menggunakan Model Project Based Learning dalam Pembuatan Media IPA berbentuk Pop Up Book. Jurnal Basicedu, 4(4), 11671175. https://doi.org/10.31004/basicedu.v4i4.518

Nursalim, N. (2017). Profesionalisme Guru Sd / Mi. Lentera Pendidikan : Jurnal Ilmu Tarbiyah Dan Keguruan, 20(2), 250-256. https://doi.org/10.24252/lp.2017v20n2i10

Ponorogo, I. (2016). Implementasi Penanaman Karakter Melalui Matematika Pada Kurikulum 2013. IBRIEZ: Jurnal Kependidikan Dasar Islam Berbasis Sains, 1(1). https://doi.org/10.21154/ibriez.v1i1.4

Purwanti, K., AR, M., \& Yusrizal, Y. (2014). Kepemimpinan Kepala Sekolah Dalam Meningkatkan Kompetensi Guru Pada Smp Negeri 2 Simeulue Timur. Jurnal Ilmiah Didaktika, 14(2), 390-400. https://doi.org/10.22373/jid.v14i2.510

Purwanti, K. L. (2017). Penerapan Literasi Lintas Kurikulum Matematika Dalam Pembelajaran Kelas Tinggi DI MIT Nurul Islam Ngaliyan Semarang Tahun 2016. Phenomenon : Jurnal Pendidikan MIPA, 7(1), 79. https://doi.org/10.21580/phen.2017.7.1.1497

Putri, N. K. I. P. (2019). Pengaruh Model Pembelajaran Group Investigation Berbantuan Media Questions Card Terhadap Pemahaman Konsep \ dan Keterampilan Berpikir Kritis IPA. Thinking Skills and Creativity Journal, 1(2), 46. https://doi.org/10.23887/tscj.v1i2.20492

Ramlawati, Yunus, S. R., \& Insani, A. (2017). Pengaruh Model PBL (Problem Based Learning) terhadap Motivasi dan Hasil Belajar IPA Peserta Didik. Jurnal Sainsmat, 6(1), 1-14. https://ojs.unm.ac.id/sainsmat/article/view/6451

Rusman, R. (2014). Meningkatkan Prestasi Belajar IPA Melalui Model Pembelajaran Kooperatif ThinkPairs Share (TPS). Pedagogia: Jurnal Pendidikan, 3(1), 67-79. https://doi.org/10.21070/pedagogia.v3i1.58

Shafa. (2014). Karakteristik Proses Pembelajaran Kurikulum 2013. Jurnal Dinamika Ilmu, 14(1), 81-96. https://doi.org/10.21093/di.v14i1.9

Sribawana, I. P. S. S., Kusmariyatni, N., \& Suwatra, I. I. W. (2017). Pengaruh Model Pembelajaran Problem Based Learning Berbantuan Media Gambar Terhadap Hasil Belajar IPA Kelas IV. Mimbar PGSD Undiksha, 5(2), 1-12. https://doi.org/10.23887/jjpgsd.v5i2.10934

Subadi, T., Priyono, K. D., Dahroni, \& Musyiyam, M. (2013). Implementasi Pembelajaran IPS Berbasis Kurikulum 2013 Melalui Lesson Study Di Sekolah Muhammadiyah Kartasura. WARTA, 18(1), 62-76. https://doi.org/10.23917/warta.v18i1.1168 
Sugiyanto, S., Kartowagiran, B., \& Jailani, J. (2015). Pengembangan Model Evaluasi Proses Pembelajaran Matematika Di SMP Berdasarkan Kurikulum 2013. Jurnal Penelitian Dan Evaluasi Pendidikan, 19(1), 82-95. https://doi.org/10.21831/pep.v19i1.4558

Wajdi, F. (2017). Implementasi Project Based Learning (PBL) Dan Penilaian Autentik Dalam Pembelajaran Drama Indonesia. Jurnal Pendidikan Bahasa Dan Sastra, 17(1), 81-97. https://doi.org/10.17509/bs_jpbsp.v17i1.6960

Wijanarko, A. G., Supardi, K. I., \& Marwoto, P. (2017). Keefektifan Model Project Based Learning Terbimbing untuk Meningkatkan Keterampilan Proses Sains dan Hasil Belajar IPA. Journal of Primary Education, 6(2), 120-125. https://doi.org/10.15294/jpe.v6i2.17561 